\title{
COMPOSITIONS FOR MOLTEN SALT PROPERTIES MEASUREMENTS
}

Nuclear Technology R \& D

Prepared for U.S. Department of Energy Molten Salt Reactor Campaign M.A. Rose and M.A. Williamson Argonne National Laboratory November 22, 2019 ANL/CFCT-19/26 


\section{DISCLAIMER}

This information was prepared as an account of work sponsored by an agency of the U.S. Government. Neither the U.S. Government nor any agency thereof, nor any of their employees, makes any warranty, expressed or implied, or assumes any legal liability or responsibility for the accuracy, completeness, or usefulness, of any information, apparatus, product, or process disclosed, or represents that its use would not infringe privately owned rights. References herein to any specific commercial product, process, or service by trade name, trade mark, manufacturer, or otherwise, does not necessarily constitute or imply its endorsement, recommendation, or favoring by the U.S. Government or any agency thereof. The views and opinions of authors expressed herein do not necessarily state or reflect those of the U.S. Government or any agency thereof. 


\section{ACKNOWLEDGEMENTS}

This report was produced under the auspices of the US DOE Office of Nuclear Energy's Nuclear Technology Research and Development Molten Salt Reactor Campaign under the direction of Dr. Lou Qualls, National Technical Director, and Mr. Brian Robinson, DOE Federal Manager. Issuance of this report meets milestone M4AT-20AN040601082.

This work was conducted at Argonne National Laboratory and supported by the U.S. Department of Energy, Office of Nuclear Energy, under Contract DE-AC02-06CH1 1357. 



\section{Compositions for Molten Salt Properties Measurements}

Work in FY20 at ANL will determine the precision of the methods being used to measure salt property values and establish standard procedures and expected data quality. This will be done by making new property measurements for several MSR-relevant salts that have been characterized previously to assess both within-laboratory and between-laboratory precisions for key property measurements. Properties to be measured include melting temperature, heat capacity, viscosity, density and thermal diffusivity.

Property measurements will be made for two representative coolant salts, a chloride-based fuel bearing salt, and a fluoride-based fuel bearing salt. The two coolant salts to be evaluated are eutectic mixtures of 46.5 LiF-11.5 NaF- 42.0 KF (mol \%) and 66 LiF-34 $\mathrm{BeF}_{2}$ (mol \%). Values for several properties of these salts have been published and both are currently being studied at Oak Ridge National Laboratory, Canadian Nuclear Laboratory, KAIROS Power and Brigham Young University. Properties of the $66 \mathrm{NaCl}-34 \mathrm{UCl}_{3}$ ( $\mathrm{mol} \%$ ) and $78.5 \mathrm{NaF}-21.5 \mathrm{UF}_{4}$ (mol \%) eutectic mixtures will be measured to represent those of chloride and fluoride-based fuel bearing salts. The $\mathrm{NaCl}-\mathrm{UCl}_{3}$ mixture is currently being studied at LANL and Washington State University, and at least one MSR developer proposed using this salt formulation. The combination of new property measurements made at ANL and values measured at other laboratories by using the same or other methods will be used to assess the precision of the measured values.

The results for these salt systems will be used to support industry development of MSR's, establish standard procedures and determine expected data quality for molten salt property measurements to be made in the future. These analyses will also provide insights for evaluating the quality of data currently available. 